\title{
Kobalamina - właściwości biomedyczne i niedobór w ujęciu biochemicznym
}

Zuzanna Rzepka, Daniel Słaby, Dorota Wrześniok*

Katedra i Zakład Chemii i Analizy Leków, Wydział Nauk Farmaceutycznych w Sosnowcu, Śląski Uniwersytet Medyczny w Katowicach

Abstrakt

Kobalamina (witamina $B_{12}$ ) jest rozpuszczalnym w wodzie związkiem organicznym, zaliczanym do witamin grupy $B$. Złożona budowa i polarność cząsteczki witaminy $B_{12}$ sprawiają, że do jej prawidłowego wykorzystania i przemian w organizmie człowieka niezbędny jest udział wyspecjalizowanych białek. Głównym źródłem kobalaminy człowieka jest pokarm pochodzenia zwierzęcego. Ze względu na rezerwy tkankowe tej witaminy, jej niedobór ujawnia się dopiero po kilku latach niewystarczającej podaży z pożywieniem. Badania przesiewowe pod kątem deficytu kobalaminy są jednak uzasadnione u osób z czynnikami ryzyka hipokobalaminemii, takimi jak: stan po resekcji żołądka lub jelita cienkiego, dieta wegańska, długotrwałe stosowanie metforminy, antagonistów receptora histaminowego $\mathrm{H}_{2}$ oraz leków $\mathrm{z}$ grupy inhibitorów pompy protonowej, a także podeszły wiek.

Witamina $B_{12}$ jako kofaktor enzymatyczny uczestniczy w licznych przemianach wewnątrzmitochondrialnych oraz w syntezie metioniny, niezbędnej do powstania S-adenozylometioniny istotnej w procesie metylacji cząsteczek biologicznie czynnych. Przez powiązania metaboliczne z kwasem foliowym kobalamina wpływa na proces syntezy DNA i podział komórki. Obecnie coraz częściej zwraca się uwagę na potencjalny udział niedoboru witaminy $\mathbf{B}_{\text {in }}$ w patogenezie chorób neurodegeneracyjnych, a także nowotworowych. Niedobór kobalaminy na poziomie molekularnym destabilizuje genom komórek, zwiększając ryzyko ich złośliwej transformacji. Jednak u osób z chorobą nowotworową lub obciążonych ryzykiem jej rozwoju witamina $B_{12}$ może nasilać ekspansję komórek neoplastycznych.

Słowa

kluczowe

kobalamina $\cdot$ hipokobalaminemia $\cdot$ witamina $B_{12}$

Otrzymano: 24.07.2020, Zaakceptowano: 29.03.2021

Abstract

Cobalamin (vitamin $B_{12}$ ) is a water-soluble organic compound that belongs to the $B$ group of vitamins. Because of the complex structure and polarity of vitamin $B_{12}$ molecule, its proper use and transformation in the human organism require the participation of specialized proteins. The main source of cobalamin for humans is food of animal origin. Due to tissue cobalamin reserves, the symptoms of its deficiency occur after several years of insufficient food supply. However, screening for cobalamin deficiency is reasonable in people with hypocobalaminemia risk factors such as gastric or small intestinal resection, vegan diet, long-term use of metformin, histamine H2-receptor antagonists, and proton pump inhibitors, as well as old age.

Vitamin $B_{12}$ as an enzyme cofactor participates in numerous intra-mitochondrial reactions and in the synthesis of methionine, which is necessary for the formation of S-adenosylmethionine, an important factor in the process of methylation of biological molecules. Through metabolic links with folic acid, cobalamin affects DNA synthesis and cell division. Currently, more and more attention is paid to the potential contribution of vitamin $B_{12}$ deficiency in the pathogenesis of neurodegenerative diseases and cancers. At the molecular level, cobalamin deficiency leads to the destabilization of cellular genome, which increases the risk of malignant transformation. On the other hand, in people with cancer or at high risk of developing it, vitamin $B_{12}$ may increase the expansion of neoplastic cells.

\section{Keywords}

cobalamin • hypocobalaminemia • vitamin B12

Received: 24.07.2020, Accepted: 29.03.2021

*Corresponding author e-mail: dwrzesniok@sum.edu.pl

(a)BY-Nc-ND (c) 2021 Zuzanna Rzepka et al. This work is licensed under the Creative Commons Attribution-NonCommercial-NoDerivs 4.0 License. 


\section{WPROWADZENIE}

Kobalamina (cobalamin, Cbl) jest rozpuszczalnym w wodzie związkiem organicznym, zaliczanym do witamin grupy B [1]. Zgodnie z definicją, „witamina” jest substancją niezbędną do prawidłowego funkcjonowania organizmu człowieka, która musi być dostarczana z zewnątrz (z pożywieniem), ze względu na brak mechanizmów umożliwiających jej syntezę w ustroju [2]. Udział kobalaminy w procesie syntezy donora metylu i kwasu deoksyrybonukleinowego (DNA) oraz w przemianach mitochondrialnych i podziale komórki powoduje, że jej deficyt ujawnia się przede wszystkim zaburzeniami neurologicznymi, nieprawidłową hematopoezą, a także może zwiększać ryzyko złośliwej transformacji komórek [3]. Witaminę $B_{12}$ po raz pierwszy wyizolowali z komórek wątroby Rickes i wsp. w 1948 r., w postaci związku o krystalicznej budowie i czerwonym zabarwieniu. Dalsze rentgenostrukturalne badania prowadzone przez D.C. Hodgkin umożliwiły opublikowanie w 1956 r. dokładnej struktury kobalaminy $[4,5]$.

\section{BUDOWA CHEMICZNA I BIOSYNTEZA KOBALAMINY}

Pod względem chemicznym witamina $B_{12}$ jest związkiem kompleksowym należącym do grupy korynoidów. W swojej strukturze zawiera makrocykliczny układ korynowy utworzony przez cztery zredukowane pierścienie pirolowe oraz centralnie położony atom kobaltu [1]. Kobalt pełniący funkcję jonu centralnego występuje na +III stopniu utlenienia i zawiera 6 ligandów: atom azotu każdego z 4 pierścieni pirolowych, azot 5,6-dimetylobenzimidazolu połączonego z resztą rybozy i grupą ortofosforanową oraz łatwo podlegający wymianie ligand $\beta$ (ryc. 1). Ligandem $\beta$ może być grupa cyjanowa,
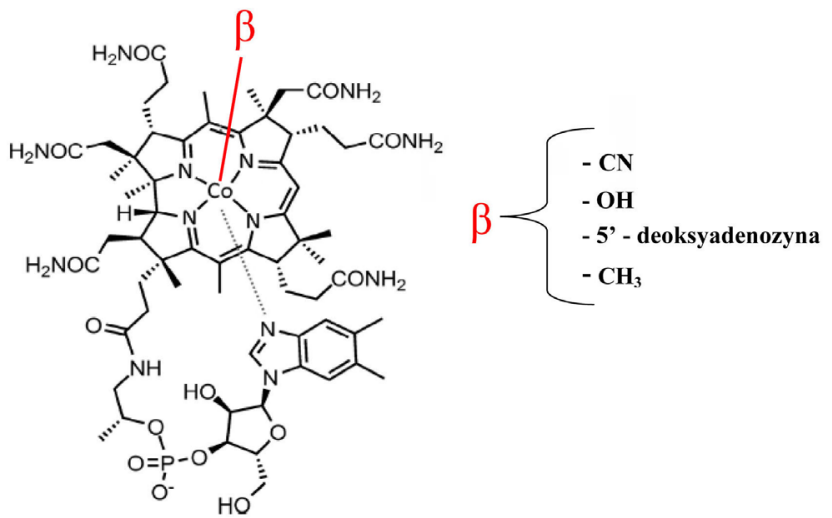

Rycina 1. Struktura witaminy B12 [na podstawie 7] hydroksylowa, 5'-deoksyadenozylowa lub metylowa, tworzące odpowiednio: cyjanokobalaminę, hydroksykobalaminę, adenozylokobalaminę i metylokobalaminę [4, 6].

Synteza witaminy $B_{12}$ jest złożonym procesem obejmującym około 25 reakcji zachodzących po sobie zarówno w warunkach tlenowych, jak i beztlenowych [7]. W środowisku naturalnym jej biosynteza przeprowadzana jest przez prokarionty - bakterie zasiedlające przewód pokarmowy przeżuwaczy i jelito grube człowieka oraz archeony, a także w znacznie mniejszych ilościach przez glony [4, 8]. Wytwarzana przez mikroflorę jelita grubego witamina nie ulega absorpcji, ponieważ synteza zachodzi poniżej miejsca optymalnego wchłaniania. Jedynym źródłem witaminy $B_{12}$ dla człowieka jest przyjmowany pokarm i suplementacja [9, 10]. Szczególnie bogate w kobalaminę są produkty pochodzenia zwierzęcego, takie jak: wątroba, nerki, skorupiaki, mięso przeżuwaczy, nabiał oraz jaja [7]. Niewielkie ilości występują również w fermentujących warzywach np. ziarnach soi [4].

\section{ŹRÓDŁO BIOLOGICZNIE AKTYWNYCH POSTACI WITAMINY $B_{12}$ W USTROJU}

Witamina $B_{12}$ powinna być dostarczana do ustroju człowieka z pokarmem lub w postaci preparatów farmaceutycznych. Dostępne są preparaty doustne, parenteralne i donosowe [11]. Wchłanianie, transport i przemiany kobalaminy w ustroju ograniczone są dużą polarnością cząsteczki, dlatego wymienione procesy wymagają obecności wyspecjalizowanych hydrofobowych białek [10]. Obecnie wiadomo, że za prawidłowe wykorzystanie Cbl z diety przez organizm odpowiada około 20 ludzkich genów [7].

Kobalamina występuje w żywności w połączeniu z matrycą białkową, z której musi oddysocjować, aby mogła ulec dalszym przemianom. Proces zachodzi pod wpływem kwaśnego $\mathrm{pH}$ soku żołądkowego i obecnego w nim enzymu: pepsyny. Po uwolnieniu witamina $B_{12}$ wiąże się z haptokoryną (haptocorrin, HC) - białkiem występującym w ślinie i treści żołądka, chroniącym witaminę przed dalszą hydrolizą kwasową [7, 12]. Kompleks Cbl-HC wraz z treścią pokarmową transportowany jest do dwunastnicy, gdzie w obecności enzymów proteolitycznych ulega degradacji. Umożliwia to połączenie kobalaminy $z$ glikoproteiną wytwarzaną przez komórki okładzinowe żołądka czynnikiem Castle'a (tzw. czynnikiem wewnętrznym; intrinsicfactor, IF) lub bezpośrednie wchłanianie wolnej kobalaminy przez ścianę jelita [4]. Wspomniany proces dyfuzji jest jednak mało wydajny, gdyż zachodzi jedynie przy wysokim gradiencie stężeń, który nie jest osiągany przy ilości witaminy $B_{12}$ występującej w pokarmie [12]. Wchłanianie kobalaminy zachodzi głównie w procesie endocytozy 
w jelicie krętym, gdzie kompleks Cbl z IF w obecności jonów $\mathrm{Ca}^{2+} \mathrm{i}$ obojętnym $\mathrm{pH}$ dostaje się do wnętrza enterocytu z udziałem receptora Cubam (zwanego też kubiliną [13]) występującego na jego powierzchni [10]. W świetle komórki jelita czynnik wewnętrzny ulega hydrolitycznemu rozkładowi, a uwolniona $\mathrm{Cbl} \mathrm{z} \mathrm{udziałem} \mathrm{m.in} \mathrm{białka} \mathrm{błonowego} \mathrm{MRP1}$ (białko oporności wielolekowej 1, multi-drug resistance protein 1) usuwana jest do krwiobiegu. Tam formowany jest kompleks kobalaminy $\mathrm{z}$ nieglikozylowanym białkiem - transkobalaminą II (transcobalamin II, TCII) - zwany holotranskobalaminą (holoTC), który łączy się ze swoistym receptorem transkobalaminy II (TCII-R) na powierzchni tkanek efektorowych i ulega internalizacji [14]. Następnie endosomy zawierające kompleks holoTC-TCII-R łączą się z lizosomami. Pod wpływem enzymów lizosomalnych dochodzi do degradacji kompleksu i uwolnienia Cbl do cytoplazmy [7, 11, 13, 15]. Gick i wsp. [15] wykazali, że receptory TCll-R nie mogą być ponownie wbudowywane w błonę komórkową, a wychwyt Cbl jest uzależniony od syntezy de novo cząsteczek tego receptora w komórce. Poziom ekspresji receptora holoTC jest zależny od fazy cyklu komórkowego. Znacznie większa ilość receptorów jest syntetyzowana w komórkach aktywnie proliferujących, m.in. komórkach nowotworowych [15].

Witamina $B_{12}$ po dostaniu się do komórki efektorowej musi ulec konwersji do jednej $z$ dwóch biologicznie aktywnych form: metylokobalaminy (MeCbl) lub adenozylokobalaminy (AdCbl), pełniących funkcje kofaktorów w odpowiednich szlakach metabolicznych [12]. W lizosomach każda forma zostaje zredukowana do podstawowego rdzenia cząsteczki kobalaminy przez odłączenie ligandu $\beta$. Następnie w cytozolu część zredukowanej kobalaminy ulega metylacji pozyskując grupę metylową z N $\mathrm{N}^{5}$-metylotetrahydrofolianu (N5 $-\mathrm{MTHF}$ ), a pozostała część tworzy AdCbl w mitochondrium. Grupa adenozylowa niezbędna do tej reakcji pozyskiwana jest z trifosforanu adenozyny [13]. Grupy metylowe i adenozylowe powstałe w czasie redukcji MeCbl i AdCbl nie są wykorzystywane do syntezy tych dwóch aktywnych kofaktorów de novo. W związku z tym uważa się, że suplementacja MeCbli AdCbl nie przyniosłaby większych korzyści niż stosowanie cyjanokobalaminy (CNCbl), która ze względu na stabilność chemiczną jest najczęściej występującą postacią witaminy $\mathrm{B}_{12}$ w preparatach farmaceutycznych [4, 11].

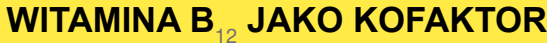 PRZEMIAN ENZYMATYCZNYCH}

Kobalamina w organizmie człowieka jest niezbędna do przebiegu reakcji katalizowanych przez syntezę metioninową (methioninesynthase, MS) oraz mutazę metylomalonyloCoA (methylmalonyl-CoAmutase, MCM) (ryc. 2) [4]. Pośredni udział witaminy w przemianach kwasu foliowego włącza ją także w szlak syntezy DNA (przemiany puryn i pirymidyn) [16].

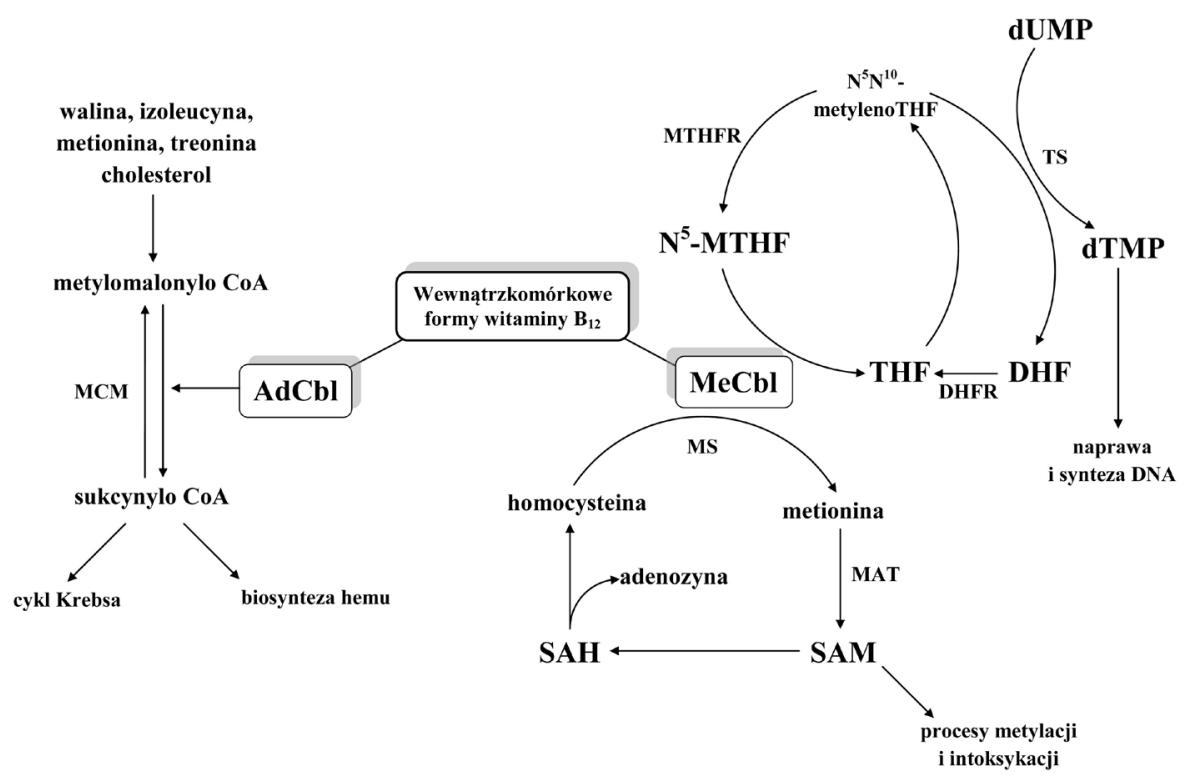

Rycina 2. Szlaki metaboliczne kobalaminy w ustroju; AdCbl - adenozylokobalamina; DHF - 7,8-dihydrofolian, DHFR - reduktaza 7,8 dihydrofolianu; dTMP - monofosforan deoksytymidyny; dUMP - monofosforoan deoksyurydyny; MAT - adenozylotransferaza metioninowa; MCM - mutaza metylomalonyloCoA; MeCbl - metylokobalamina; MS - syntaza metioninowa; MTHFR - reduktaza metylenotetrahydrofolianu; N5 MTHF - N5-metylotetrahydrofolian; SAH - S adenozylohomocysteina; SAM - S-adenozylometionina; THF - tetrahydrofolian; TS - syntaza tymidylanowa [na podstawie 7,12 ] 
Syntaza metioninowa jest enzymem cytozolowym, który z udziałem MeCbl przeprowadza reakcje syntezy metioniny w procesie metylacji homocysteiny. Donorem grupy metylowej homocysteiny jest $\mathrm{N}^{5}$-MTHF, który jednocześnie ulega demetylacji do tetrahydrofolianu (THF). Wolna cząsteczka aktywnego folianu - THF jest niezbędna do aktywności syntazy tymidylanowej (thymidylate synthase, TS) oraz transportu jednowęglowych ugrupowań koniecznych do syntezy zasad azotowych [7, 17]. Powstająca metionina staje się prekursorem S-adenozylometioniny (SAM), związku będącego dawcą grupy metylowej $w$ procesie metylacji DNA, neurotransmiterów i hormonów, a także inaktywacji toksycznych związków aromatycznych [12]. Po oddaniu grupy metylowej w reakcji katalizowanej przez metylotransferazy, SAM przechodzi w S-adenozylo-homocysteinę (SAH), ulegającą rozkładowi do adenozyny i homocysteiny $[8,16]$.

Druga aktywna biologicznie postać kobalaminy: adenozylokobalamina jest w organizmie człowieka kofaktorem mutazy metylomalonylokoenzymu A. Enzym ten w mitochondrium katalizuje reakcję konwersji metylomalonyloCoA do sukcynylo-CoA, który jest włączany w cykl kwasów trikarboksylowych (cykl Krebsa) oraz w szlak syntezy hemu [8, 19]. Mutaza metylomalonylokoenzymu A odgrywa kluczową rolę $w$ katabolizmie aminokwasów: waliny, izoleucyny, treoniny, metioniny oraz kwasów tłuszczowych o nieparzystej liczbie atomów węgla i cholesterolu. Szkielety węglowe tych związków z udziałem biotyny oraz AdCbl są przekształcane do propionylo-CoA, metylomalonylo-CoA i sukcynylo-CoA, stając się źródłem energii w cyklu Krebsa [12].

\section{ETIOLOGIA STANU HIPOKOBALAMINEMII}

Nadmiar kobalaminy $w$ organizmie magazynowany jest głównie w wątrobie. Szacuje się, że zapasy tkankowe tej witaminy wynoszą $5 \mathrm{mg}$, co oznacza, że objawy jej niedoboru mogą się pojawić dopiero po około 3 latach od całkowitego braku jej podaży. Spożycie kobalaminy u osób dorosłych powinno wynosić około 1,5 $\mu \mathrm{g} /$ dobę [20]. Prawidłowo zbilansowana dieta może pokryć dzienne zapotrzebowanie na kobalaminę [21]. Mimo to istnieje wiele zaburzeń wywołujących niedobór witaminy $B_{12}$ (hipokobalaminemii). Szczególnie niebezpieczny jest stan utajonego niedoboru, gdy deficyt kobalaminy jest maskowany nadmierną suplementacją kwasu foliowego [17].

Niewystarczająca podaż witaminy $B_{12}$ do komórek efektorowych może być spowodowana czynnikami egzo- lub endogennymi. Do czynników pozaustrojowych zalicza się niedobór kobalaminy $w$ diecie, obserwowany szczególnie u osób starszych, alkoholików i anorektyków (niedożywienie) oraz wegetarian i wegan (niewielka ilość lub brak spożycia produktów pochodzenia zwierzęcego) [10, 14]. Jak wykazały badania, w Stanach Zjednoczonych i Wielkiej Brytanii niedobór witaminy $\mathrm{B}_{12}$ występuje $\mathrm{u}$ około $6 \%$ osób w wieku poniżej 60 lat i prawie $20 \%$ osób w wieku powyżej 60 . roku życia. Wartości te są znacznie wyższe w krajach trzeciego świata i korelują ze wzrostem wskaźnika niedożywienia [3]. Do najważniejszych czynników endogennych zalicza się zaburzenia wchłaniania witaminy z pokarmu, tzw. zespół złego wchłaniania kobalaminy (food-bound kobalamin mal absorption, FBCM). Zespół FBCM spowodowany jest niezdolnością uwalniania kobalaminy z matrycy białkowej w pokarmie jak i z połączeń z białkami transportowymi w wyniku wzrostu pH i zmniejszenia ilości soku żołądkowego $[3,21]$. Dlatego u pacjentów przewlekle przyjmujących leki z grupy inhibitorów pompy protonowej oraz antagonistów receptora histaminowego $\mathrm{H}_{2}$ - zmniejszających wytwarzanie kwasu solnego, występuje dużo większe ryzyko rozwoju hipokobalaminemii. Spadek kwasowości soku żołądkowego przyczynia się także do rozrostu mikroflory jelitowej wykorzystującej znaczne ilości kobalaminy [3, 17]. Coraz częściej zwraca się również uwagę na związek między terapią metforminą, lekiem pierwszego wyboru $w$ terapii cukrzycy typu II, a obniżonym stężeniem witaminy $\mathrm{B}_{\text {a }}$ w surowicy. Etiologia tego zjawiska nie jest wyjaśniona, jednak przypuszcza się, że wiąże się z zaburzeniem zależnego od wapnia wchłaniania kompleksu IF-Cbl w jelicie $[14,22]$. Do przyczyn rozwoju FBCM zalicza się również defekty białek transportujących kobalaminę. Zaburzenie wytwarzania i czynnika IF warunkującego wchłanianie witaminy do enterocytów występuje w przebiegu zanikowego zapalenia błony śluzowej żołądka, choroby AddisonaBiermera, długotrwałego zakażenia bakterią Helicobacter pylori oraz po częściowej gastrektomii [3]. Do innych schorzeń predysponujących do rozwoju hipokobalaminemii należą: zespół Crohna, zespół Zollingera-Ellisona, celiakia, zakażenia pasożytnicze oraz zaburzenia genetyczne, do których zalicza się między innymi wrodzony niedobór transkobalaminy II oraz zespół Imerslund-Grasbecka, związany z mutacją w genie kodującym kubilinę $[21,23]$.

\section{WITAMINA B A STABILNOŚĆ GENOMU}

\section{Wpływ niedoboru witaminy $B_{12}$ na procesy metylacji DNA i poziom homocysteiny}

Witamina $B_{12}$ oraz kwas foliowy odgrywają znaczącą rolę w utrzymaniu właściwego poziomu metylacji cząsteczek biologicznych, w tym DNA [24]. Proces ten należy do epigenetycznych zmian $w$ obrębie genomu, zależnych od środowiska zewnętrznego, regulujących poziom ekspresji i funkcję genów. W przeciwieństwie do mutacji nie dotyczy on jednak sekwencji nukleotydów, a jest jedynie 
enzymatyczną poreplikacyjną modyfikacją. Proces metylacji polega na przeniesieniu grup metylowych z SAM z udziałem odpowiednich metylotransferaz i ich kowalencyjnym wiązaniu z zasadami azotowymi DNA [25, 26]. W materiale genetycznym człowieka około $4 \%$ cytozyny występuje w postaci zmetylowanej: 5-metylocytozyny, a jej znaczna część znajduje się w obrębie wysp 5'-CpG-3', stanowiących regiony o zwiększonej, w porównaniu do pozostałej części DNA, liczbie par zasad cytozyna-guanina. Metylacja tych regionów hamuje aktywność układów transkrypcyjnych, prowadząc do wyciszenia genów. Poziom metylacji wysp CpG występujących w obrębie promotorów genów regulatorowych jest istotny $w$ prawidłowym przebiegu podziałów komórkowych. Pozostają one najczęściej niezmetylowane, co umożliwia syntezę białek kontrolujących cykl komórkowy [16, 26].

Zarówno MeCbl jak i N5-MTHF są związkami niezbędnymi do syntezy metioniny (ryc. 2), z której w następnej reakcji powstaje donor grupy metylowej - S-adenozylometionina [12]. Zaburzenia w podaży tych substancji przyczyniają się do zmian wewnątrzkomórkowego poziomu SAM, skutkując hipo- lub hipermetylacją genomu [27]. Z dostępnych źródeł literaturowych jednoznacznie wynika związek między zmianami poziomu metylacji DNA a wczesnymi etapami procesu nowotworowego. Ogniska hipo- i hipermetylacji obserwuje się w obrębie genów, swoistych dla danego typu nowotworu [16]. Są to najczęściej geny kodujące białka biorące udział $w$ regulacji cyklu komórkowego i procesu apoptozy. Zmniejszona metylacja będąca skutkiem m.in. niedoboru kobalaminy, może doprowadzić do nadekspresji onkogenów, których produkty powodują niekontrolowaną proliferację komórek i kancerogenezę [25, 28]. Obniżony poziom metylacji zaobserwowano m.in. w nowotworach żołądka, jelita grubego, piersi i tarczycy. Wykazano również indukcję hipometylacji limfocytowego ludzkiego DNA wywołaną dietą $\mathrm{z}$ niedoborem kwasu foliowego, znacznie nasiloną jednoczesnym deficytem witaminy $B_{12}$ lub metioniny [29]. W przeciwieństwie do hipometylacji, zjawisko nadmiernej metylacji doprowadza do wyciszenia ekspresji genu [16]. Dla onkogenezy istotna jest hipermetylacja w obrębie genów supresorowych, których produkty hamują procesy proliferacji uszkodzonych komórek [28]. Hipermetylację promotora genu supresorowego P16 (INK4) stwierdzono w przebiegu nowotworu pęcherza moczowego, gardła, płuc, w czerniaku, a także glejaku. Produkt tego genu, białko p16 zwane też inhibitorem kinazy cyklinozależnej, w prawidłowych ilościach hamuje wejście komórek w fazę $G_{1}$ cyklu komórkowego. Jego zmniejszona synteza skutkuje niekontrolowanymi podziałami komórkowymi inicjującymi proces nowotworzenia [16, 29].

Zmniejszone stężenie S-adenozylometioniny, wywołujące hipometylację $\mathrm{z}$ niedoboru kobalaminy i/ lub kwasu foliowego, jest jednocześnie związane z gromadzeniem się S-adenozylohomocysteiny, silnego inhibitora metylaz, a także niebiałkowego, siarkowego aminokwasu: homocysteiny (HCY) [28]. Nadmiar HCY może zaburzać wewnątrzkomórkowy system antyoksydacyjny oraz prowadzić do generowania reaktywnych form tlenu (reactive oxygen species, ROS), co w dużym stopniu przyczynia się do

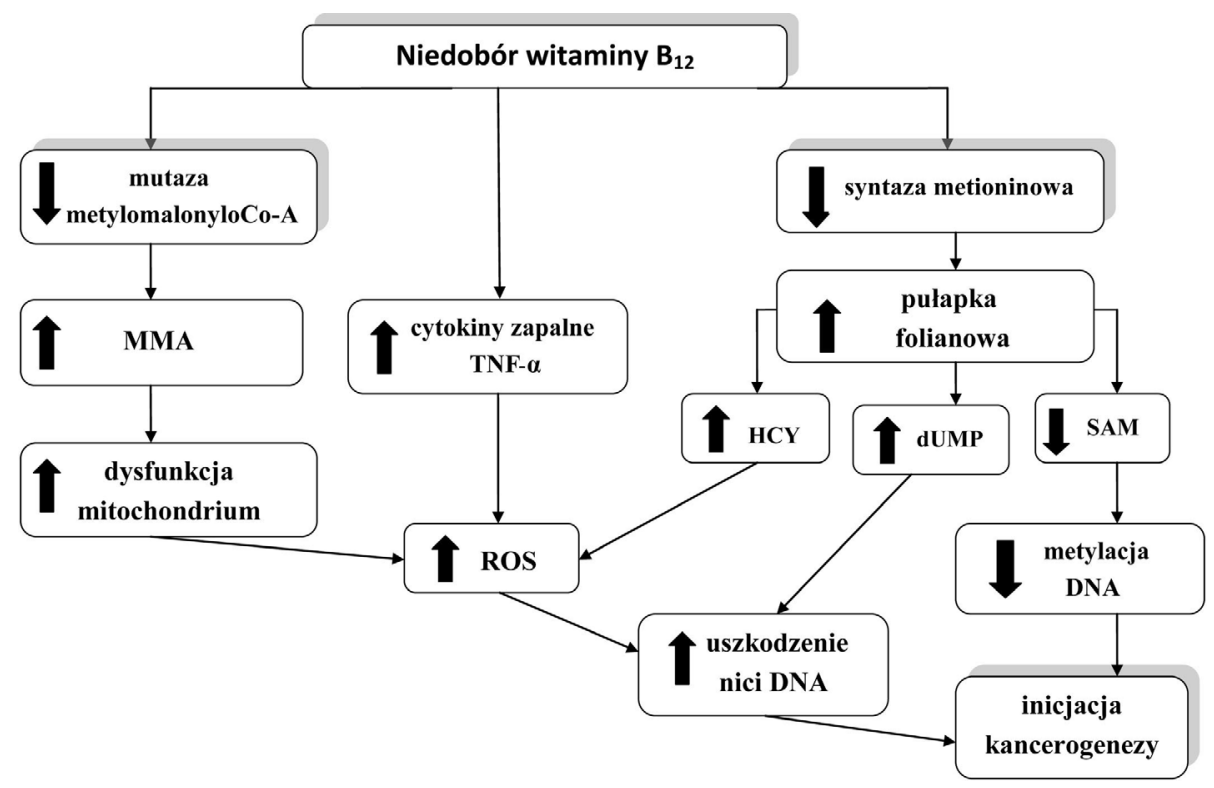

Rycina 3. Wpływ niedoboru witaminy $B_{12}$ na genom komórek prawidłowych i inicjację kancerogenezy; dUMP - mononukleotyd urydynowy; HCY - homocysteina MMA - kwas metylomalonowy; ROS - reaktywne formy tlenu; SAM - S-adenozylometionina; TNF- $\alpha$ - czynnik martwicy nowotworu a [na podstawie 28,29] 
rozwoju powikłań naczyniowych hiperhomocysteinemii [25]. ROS powstają również $w$ wyniku wywołanego niedoborem $B_{12}$ wzrostu poziomu cytokin zapalnych m.in. TNF-a (tumor necrosis factor $\alpha$ ), ale i zaburzenia metabolizmu mitochondrialnego. Brak kofaktora - mutazy metylomalonylo CoA - skutkuje gromadzeniem się w mitochondrium kwasu metylomalonowego (methylmalonicacid, MMA), nasilając stres oksydacyjny. Powstające ROS mogą uszkadzać DNA i powodować jego destabilizację, przyczyniając się do kancerogenezy [27, 30].

\section{Pułapka folianowa}

Kobalamina pośrednio uczestniczy w procesie syntezy i naprawy DNA. Spowodowana jej deficytem niewydolność szlaku syntezy metioniny doprowadza do tzw. pułapki folianowej [16]. Niemożność wykorzystania $\mathrm{N}^{5}$-MTHF $w$ reakcji metylacji homocysteiny powoduje jego nagromadzenie i zmniejsza ilość aktywnego folianu - THF. Obniża się poziom $\mathrm{N}^{5} \mathrm{~N}^{10}$-metylenoTHF i zaburzeniu ulega reakcja konwersji mononukleotydu urydynowego (dUMP) do tymidyny (dTMP) oraz proces syntezy puryn de novo [25, 28]. Zmniejszona ilość tyminy, wobec gromadzącego się uracylu, powoduje jego błędne wbudowywanie do nici DNA. Zjawisko to jest bardzo mutagenne, jednak dzięki obecności enzymu naprawczego: glikozydazy uracylowej DNA (uracil-DNA glycosylase, UDG), nieprawidłowo wbudowany nukleotyd może zostać wycięty. Postępujący niedobór kobalaminy lub kwasu foliowego sprawia, że system naprawczy staje się niewydolny i pojawiają się jedno- lub dwuniciowe pęknięcia nici DNA oraz aberracje chromosomowe powodujące całkowitą destabilizację genomu i wzrost ryzyka złośliwej transformacji (ryc. 3) $[16,28,30]$.

\section{WITAMINA B A PROCES KANCEROGENEZY}

Stan długotrwałego niedoboru kobalaminy, poprzez mechanizmy przedstawione na ryc. 3, powoduje istotne uszkodzenia DNA, które zaburzają proces replikacji komórek prawidłowych i inicjują proces nowotworowy [28]. Wpływ witamin grupy B na proces nowotworowy jest niewątpliwy. Rola ta jest jednak niejednoznaczna, a jej charakter zależy od rodzaju nowotworu, dawki substancji, a przede wszystkim stanu fizjologicznego komórek [24, 32].

Analiza wyników badań retrospektywnych i prospektywnych wskazuje na dwojaką rolę witaminy $B_{\text {a }}$ i kwasu foliowego $w$ procesie kancerogenezy [33, 34]. Informacje o wpływie witaminy $B_{12}$ na stabilność genomu świadczą o potencjalnie chemoprewencyjnym działaniu suplementacji kobalaminy, jak również kwasu foliowego [24]. Wykazano, że u osób spożywających pokarmy bogate w kwas foliowy, zmniejsza się o 40-60\% ryzyko rozwoju raka jelita grubego [34]. Analogiczna zależność wykazano również dla nowotworów sutka, jajnika, macicy, płuc oraz trzustki [32].

Należy podkreślić, że chemoprewencyjne działanie kobalaminy i kwasu foliowego odnosi się jedynie do komórek prawidłowych. Paradoksalnie, duże dawki tych substancji u osób z zaawansowanymi zmianami nowotworowymi bądź posiadających zmiany dysplastyczne mogą nasilić ekspansję nowotworu [34]. Badania epidemiologiczne, kliniczne i eksperymentalne wskazują na dodatnią korelację między nadmierną ilością witaminy $B_{12} i$ kwasu foliowego a progresją zmian nowotworowych [32, 35]. W badaniu interwencyjnym, któremu poddano osoby ze zdiagnozowanymi gruczolakami jelita grubego, po zastosowaniu dużych dawek kobalaminy i kwasu foliowego zaobserwowano dalszą przyspieszoną hiperplazję nabłonka w kierunku nowotworu złośliwego [31]. Duże dawki tych witamin przyspieszają także pojawienie się zmian nowotworowych u osób obciążonych ryzykiem raka prostaty, sutka i krtani $[35,36]$.

Mimo iż destabilizacja genomu (np. w wyniku niedoboru kobalaminyi/lub kwasu foliowego) leżyu podstaw onkogenezy, coraz częściej postuluje się wykorzystanie wewnętrznego stresu replikacyjnego $w$ komórce neoplastycznej w celowanej terapii przeciwnowotworowej $[37,38]$. Witamina $B_{12}$ i kwas foliowy, jako kofaktory syntezy puryn i tyminy, odgrywaja ważną rolę $w$ replikacji DNA. Zaburzenie metabolizmu folianów, z powodu ich niedoboru w szybko replikujących się komórkach nowotworowych, zaburza ich podział i hamuje wzrost guza [32]. Wywołanie stresu replikacyjnego w tkance

Tabela 1. Objawy neurologiczne niedoboru witaminy $B_{12}-$ podział ze względu na lokalizację uszkodzenia [na podstawie 17,40]

\begin{tabular}{cc}
\hline Lokalizacja uszkodzenia & Objawy \\
\hline Sznury tylne rdzenia kręgowego & Niezborność ruchowa, zaburzenia równowagi, utrata czucia wibracyjnego, dodatni objaw Romberga \\
Sznury boczne rdzenia kręgowego & Spastyczne napięcia mięśni, brak siły mięśniowej, dodatni objaw Babińskiego \\
Nerwy obwodowe & Zaburzenie ostrości wzroku, połowiczne niedowidzenie, ślepota \\
Istota biała mózgu & Zaburzenie odruchów ścięgnistych (głębokich) i funkcji zwieraczy, osłabienie mięśni kończyn i ich zanik \\
\hline
\end{tabular}


nowotworowej może zatem przynieść spodziewane korzyści terapeutyczne. Zjawisko to było podstawą zastosowania w terapii przeciwnowotworowej związków działających antagonistycznie do folianów (antyfoliany) m.in. metotreksatu.

\section{SKUTKI NIEDOBORU KOBALAMINY}

Jednym z objawów niedoboru kobalaminy są zaburzenia ze strony układu nerwowego [17]. Badania histopatologiczne wykazały, iż brak witaminy $B_{12}$ powoduje demielinizację neuronów rdzenia kręgowego, nerwów obwodowych oraz istoty białej mózgu (tab. 1). Uszkodzenie neuronów przyczynia się również do astrogliozy, tj. stanu patologicznej aktywacji astrocytów [39].

Za główne przyczyny wymienionych zaburzeń, zwanych podostrą połączoną degeneracją rdzenia (subacute combined degeneration, SCD), uważa się zmniejszenie poziomu SAM i wzrost stężenia MMA obserwowane w stanie niedoboru witaminy $B_{12}[17,40]$. Niedobór SAM w ośrodkowym układzie nerwowym zaburza proces metylacji fosfolipidów, m.in. fosfatydylocholiny będącej składnikiem mieliny, co skutkuje nieprawidłowym przewodnictwem neuronalnym objawiającym się encefalopatią i mielopatią. Ponadto gromadząca się w stanie hipokobalaminemii homocysteina może bezpośrednio działać neurotoksycznie przez aktywację receptora $\mathrm{N}$-metylo-D-asparaginianowego (NMDA), a także powodować uszkodzenia oksydacyjne [18, 39].

Zaburzenia konwersji metylmalonylo-CoA do sukcynyloCoA powodują kumulację kwasu metylomalonowego w mitochondrium, a to upośledza metabolizm kwasów tłuszczowych. Nieprawidłowe, rozgałęzione kwasy tłuszczowe są wbudowywane do lipidów neuronów i osłonek mielinowych, doprowadzając do demielinizacji wskutek przerwania integralności struktury mieliny i wadliwej transmisji neuronalnej $[8,17]$. Początkowe objawy neuropatii przyjmują postać parestezji kończyn (drętwienie, mrowienie). W miarę postępu choroby stwierdza się utratę czucia, zmniejszoną propriocepcję, zaburzenia ruchowe i spastyczne porażenie kończyn dolnych [21, 23].

Niedobór kobalaminy może się również ujawniać pod postacią zaburzeń neuropsychiatrycznych. Uważa się, że wynikają one z niedoboru S-adenozylometioniny zaangażowanej w syntezę neuroprzekaźników. Nieprawidłowe stężenie serotoniny, noradrenaliny i dopaminy powoduje zmiany psychiczne obejmujące: stany depresyjne, objawy maniakalne lub ostre psychozy [18, 23]. Przewlekły deficyt witaminy $B_{12}$ może również doprowadzić do rozwoju otępienia o charakterze podkorowym, objawiającego się spowolnieniem psychoruchowym, zaburzeniem koncentracji uwagi i demencją. Obecnie coraz częściej zwraca się uwagę na potencjalną rolę niedoboru witaminy $B_{12}$ i podwyższonego poziomu homocysteiny w patogenezie otępienia naczyniopochodnego i choroby Alzheimera [17, 40].

Deficyt witaminy $B_{12}$ na poziomie komórkowym może prowadzić do indukcji stresu siateczki endoplazmatycznej (endoplasmic reticulum, ER) przez hamowanie ekspresji sirtuiny 1 [41]. Liczne badania wykazały, iż długotrwały stres ER w komórkach ośrodkowego układu nerwowego odgrywa znaczącą rolę w patogenezie chorób neurodegeneracyjnych, m.in. chorobie Parkinsona i chorobie Huntingtona [42].

Zakłócenia szlaków syntezy DNA w stanie niedoboru kobalaminy są przyczyną zaburzeń homeostazy komórek szybko dzielących się, co ujawnia się zmianami m.in. w obrębie układu krwiotwórczego (anemia makrocytarna), pokarmowego, rozrodczego i skóry (tab. 2) [14]. Anemia makrocytarna charakteryzuje się obecnością we krwi nienaturalnie dużych i słabo rozwiniętych erytrocytów o upośledzonej funkcji tzw. megaloblastów [39]. Zaburzona synteza nukleotydów uniemożliwia wejście komórek w fazę $\mathrm{G}_{2}$ cyklu komórkowego, co skutkuje dużym rozmiarem krwinek, a indukcja apoptozy przyczynia się do pancytopenii, czyli niedoboru wszystkich elementów morfotycznych krwi [17, 43]. Symptomami klinicznymi tej choroby są: bladość skóry, zaburzenia oddychania, szybkie męczenie się oraz

Tabela 2. Objawy niedoboru kobalaminy (z wyłączeniem objawów ze strony układu nerwowego) [na podstawie 3,5]

\begin{tabular}{|c|c|}
\hline Rodzaj zaburzenia & Objawy kliniczne \\
\hline Pokarmowe & $\begin{array}{c}\text { Zapalenie języka (tzw. bawoli język), zanik brodawek języka, zaburzenia smaku, uczucie pieczenia w jamie ustnej, biegunka, } \\
\text { nudności, bóle brzucha }\end{array}$ \\
\hline Hematologiczne & Anemia makrocytarna, pancytopenia \\
\hline Ginekologiczne & Zanik błony śluzowej pochwy, infekcje dróg moczowych (grzybice), powtarzające się poronienia \\
\hline Sercowo-naczyniowe & $\begin{array}{l}\text { Hiperhomocysteinemia będąca czynnikiem ryzyka zaburzeń zakrzepowo-zatorowych; udar mózgu, niedokrwienie mięśnia } \\
\text { sercowego }\end{array}$ \\
\hline Inne & $\begin{array}{l}\text { Przebarwienia (hiperpigmentacje) skóry i błon śluzowych, bladość skóry o odcieniu żołto-cytrynowym z ogniskami bielactwa, } \\
\text { zażółcenie białkówek, bolesne owrzodzenia w kącikach ust, przedwczesne siwienie włosów }\end{array}$ \\
\hline
\end{tabular}


bóle i zawroty głowy. Niemniej jednak anemia makrocytarna przez wiele lat może pozostawać bezobjawowa [5].

\section{DIAGNOSTYKA I MARKERY NIEDOBORU KOBALAMINY}

Odpowiednio wczesne wykrycie niedoboru witaminy $B_{12}$ może zapobiec nieodwracalnym zmianom klinicznym. Niedobór kobalaminy jest jednak trudny do zdiagnozowania [44]. Badania dowodzą, iż objawy kliniczne hipokobalaminemii nie zawsze są związane $z$ jej niskim poziomem w surowicy. Znacznie lepsze rezultaty daje pomiar stężenia markerów hipokobalaminemii: kwasu metylomalonowego i homocysteiny, kumulujących się w organizmie na skutek deficytu Cbl [14, 45]. Mimo iż wzrost HCY może wynikać również $\mathrm{z}$ niedoboru witaminy $\mathrm{B}_{6} \mathrm{i}$ kwasu foliowego, a wzrost MMA obserwowany jest $w$ niewydolności nerek, jednoczesne przekroczenie norm obu tych wskaźników świadczy o stanie niedoboru kobalaminy [21]. Wartości referencyjne tych parametrów zależą m.in. od metody oznaczenia i różnią się w poszczególnych laboratoriach. Według uśrednionych danych wartości poniżej $148 \mathrm{pmol} / \mathrm{l}$ wolnej kobalaminy i powyżej $15 \mu \mathrm{mol} / \mathrm{l}$ i $0,35 \mu \mathrm{mol} / /$ odpowiednio HCY i MMA mogą świadczyć o hipokobalaminemii [22].

Obniżony poziom holotranskobalaminy jest wczesnym markerem deficytu kobalaminy. To połączenie witaminy z transkobalaminą II jest jedyną postacią, która może ulec endocytozie do komórek, dlatego jej poziom w surowicy dobrze koreluje ze stężeniem wewnątrzkomórkowym m.in. w erytrocytach. Prawidłowy zakres stężeń holoTC u osób zdrowych wynosi 20-125 pmol/l [22, 44].

Obecnie za parametr o największej wartości diagnostycznej uznaje się kombinowany wskaźnik poziomu witaminy $B_{12}$ (combined indicato of vitamin $B_{12}$ status, $\mathrm{cB}_{12}$ ). Jego wartość, która nie powinna być mniejsza niż 0,5 jest wyliczana na podstawie algorytmu uwzględniającego stężenie wolnej Cbl, holoTC, MMA i HCY [45].

\section{PODSUMOWANIE}

Kobalaminajest kofaktorem wewnątrzkomórkowych przemian istotnych dla prawidłowego funkcjonowania organizmu. Tkankowe zapasy i zróżnicowana dieta umożliwiają pokrycie dziennego zapotrzebowania na kobalaminę, jednak do jej wewnątrzustrojowego deficytu mogą się przyczynić czynniki endogenne (m.in. podeszły wiek, stosowanie metforminy i/ lub leków obniżających kwasowość soku żołądkowego) oraz defekty genetyczne. Stan hipokobalaminemii może wywołać zaburzenia ze strony układu krwiotwórczego, proces neurodegeneracji, jak również doprowadzić do złośliwej transformacji komórek. Wczesne wykrycie niedoboru witaminy $\mathrm{B}_{12} \mathrm{i}$ podjęcie terapii opartej o suplementację zapobiega rozwojowi nieodwracalnych zaburzeń homeostazy organizmu. Dlatego istotne jest przeprowadzanie badań diagnostycznych w kierunku niedoboru kobalaminy u osób o podwyższonym ryzyku wystąpienia hipokobalaminemii.

\section{Wykaz skrótów}

AdCbl - adenozylokobalamina (adenosylcobalamin); $\mathbf{c B}_{12}$ - kombinowany wskaźnik poziomu witaminy $\mathbf{B}_{12}$ (combined indicator of vitamin $\mathrm{B}_{12}$ status); $\mathrm{Cbl}$ - kobalamina (cobalamin); CNCbI - cyjanokobalamina (cyanocobalamin); DHF - 7,8-dihydrofolian (7,8-dihydrofolate); DHFR reduktaza 7,8-dihydrofolianu (7,8-dihydrofolate reductase); DNA - kwas deoksyrybonukleinowy (deoxyribonucleic acid); dTMP - monofosforan deoksytymidyny (deoxythymidine monophosphate); dUMP - monofosforan deoksyurydyny (deoxyuridine monophosphate); ER siateczka endoplazmatyczna (endoplasmic reticulum); FBCM - zespół złego wchłaniania kobalaminy (foodbound cobalamin malabsorption); HC - haptokoryna (haptocorin); HCY - homocysteina (homocysteine); holoTC - holotranskobalamina (holotranscobalamin); IF - czynnik wewnętrzny Castle'a (intrinsic factor); INK4 rodzina inhibitorów kinaz cyklinozależnych (CDK4, CDK6) (inhibitors of CDK4 and CDK6); MAT - adenozylotransferaza metioninowa (methionine adenosyltransferase); MCM mutazametylomalonylo-CoA (methylmalonyl-CoA mutase); MeCbI - metylokobalamina (methylcobalamin); MMA - kwas metylomalonowy (methylmalonic acid); MRP1 białko oporności wielolekowej 1 (multi-drug resistance protein 1); MS - synteza metioninowa (methionine synthase); MTHFR - reduktaza metylenotetrahydrofolianu (methylenetetrahydrofolate reductase); $\mathbf{N}^{5}-\mathbf{M T H F}-\mathrm{N}^{5}$ metylotetrahydrofolian ( $\mathrm{N}^{5}$-methyltetrahydrofolate); $\quad$ p16 - białko kodowane przez gen CDKN2A, inhibitor kinaz cyklinozależnych (multiple tumor suppressor 1, p16 ${ }^{\text {INK4a }}$ ); ROS - reaktywne formy tlenu (reactive oxygen species); SAH S-adenozylohomocysteina (S-adenosylhomocysteine); SAM - S-adenozylometionina (S-adenosylmethionine); SCD podostra połączona degeneracja rdzenia (subacute combined degeneration); TCII - transkobalamina II (transcobalamin II); TCII-R-błonowy receptor transkobalaminy II (transcobalamin II receptor); THF - tetrahydrofolian (tetrahydrofolate); TS - synteza tymidylanowa (thymidylate synthase); UDG glikozydaza uracylowa DNA (uracil-DNA glycosylase). 


\section{Konflikt interesów}

Autorzy deklarują brak potencjalnych konfliktów interesów.

\section{Finansowanie}

Praca powstała $\mathrm{w}$ wyniku realizacji projektu badawczego nr PCN-2-044/K/0/F finansowanego ze środków Śląskiego Uniwersytetu Medycznego w Katowicach.

\section{Piśmiennictwo}

[1] Katarzyńska J.: Potencjał aplikacyjny witaminy B12 i jej analogów. Eliksir, 2016; 2: 11-18

[2] Kräutler B.: Antivitamins B12 - a structure- and reactivity-based concept. Chemistry, 2015; 21: 11280-11287

[3] Langan R.C., Goodbred A.J.: Vitamin B12 deficiency: Recognition and management. Am. Fam. Physician., 2017; 96: 384-389

[4] Kośmider A., Czaczyk K.: Witamina $B_{12}$ - budowa, biosynteza, funkcje i metody oznaczania. Żywn. Nauka Technol. Jakość, 2010; 5: 17-32

[5] Mziray M., Domagała P., Żuralska R., Siepsiak M.: Witamina B12 - skutki niedoboru, zasadność terapii i suplementacji diety u osób w wieku podeszłym. Pol. Prz. Nauk Zdr., 2016; 3: 295-301

[6] Zelder F.: Recent trends in the development of vitamin $B_{12}$ derivatives for medical applications. Chem. Commun., 2015; 51: 1400414017

[7] Froese D.S., Fowler B., Baumgartner M.R.: Vitamin $B_{12}$, folate, and the methionine remethylation cycle - biochemistry, pathways, and regulation. J. Inherit Metab. Dis., 2019; 42: 673-685

[8] Xu Y., Xiang S., Ye K., Zheng Y., Feng X., Zhu X., Chen J., Chen Y.: Cobalamin (vitamin B12) induced a shift in microbial composition and metabolic activity in an in vitro colon simulation. Front. Microbiol., 2018; 9: 2780

[9] Rowley C.A., Kendall M.M.: To B12 or not to B12: Five questions on the role of cobalamin in host-microbial interactions. PLoS Pathog., 2019; 15: e1007479

[10] Watkins D., Rosenblatt D.S.: Inborn errors of cobalamin absorption and metabolism. Am. J. Med. Genet. C Semin. Med. Genet., 2011; 157C: 33-44

[11] Obeid R., Fedosov S.N., Nexo E.: Cobalamin coenzyme forms are not likely to be superior to cyano- and hydroxyl-cobalamin in prevention or treatment of cobalamin deficiency. Mol. Nutr. Food Res., 2015; 59: 1364-1372

[12] Paul C., Brady D.M.: Comparative bioavailability and utilization of particular forms of $B_{12}$ supplements with potential to mitigate $B_{12}-$ related genetic polymorphisms. Integr. Med., 2017; 16: 42-49

[13] Quadros E.V.: Advances in the understanding of cobalamin assimilation and metabolism. Br. J. Haematol., 2010; 148: 195-204
[14] Socha D.S., DeSouza S.I., Flagg A., Sekers M., Rogers H.J.: Severe megaloblastic anemia: Vitamin deficiency and other causes. Cleve. Clin. J. Med., 2020; 87: 153-164

[15] Gick G.G., Arora K., Sequeira J.M., Nakayama Y., Lai S.C., Quadros E.V.: Cellular uptake of vitamin $B_{12}$ : Role and fate of TCbIR/ $C D 320$, the transcobalamin receptor. Exp. Cell. Res., 2020; 396: 112256

[16] Kalemba-Drożdż M.: Niedobory folianów w diecie i ich wpływ na stabilność genetyczną. W: Interdyscyplinarne aspekty nauk o zdrowiu, red.: G. Dębska, J. Jaśkiewicz. Krakowskie Towarzystwo Edukacyjne sp. z o.o. - Oficyna Wydawnicza AFM, Kraków 2010, 21-31

[17] Briani C., Torre C.D., Citton V., Manara R., Pompanin S., Binotto G., Adami F.: Cobalamin deficiency: Clinical picture and radiological findings. Nutrients, 2013; 5: 4521-4539

[18] Singh N.N., Thomas F.P., Diamond A.L.: Vitamin B-12 associated neurological diseases clinical presentation. Medscape, 2018. https://emedicine.medscape.com/article/1152670-clinical (28.02.2020)

[19] Takahashi-Iñiguez T., García-Hernandez E., Arreguín-Espinosa R., Flores M.E.: Role of vitamin $B_{12}$ on methylmalonyl-CoA mutase activity. J. Zhejiang Univ. Sci. B, 2012; 13: 423-437

[20] Government Dietary Recommendations. Government recommendations for energy and nutrients for males and females aged $1-18$ years and 19+ years. Public Health England, 2016. https:// assets.publishing.service.gov.uk/government/uploads/system/uploads/attachment_data/file/618167/government_dietary_recommendations.pdf (12.01.2020)

[21] Shipton M.J, Thachil J.: Vitamin B12 deficiency - A 21st century perspective. Clin. Med., 2015; 15: 145-150

[22] Hannibal L., Lysne V., Bjørke-Monsen A.L., Behringer S., Grünert S.C., Spiekerkoetter U., Jacobsen D.W., Blom H.J.: Biomarkers and algorithms for the diagnosis of vitamin $B_{12}$ deficiency. Front. Mol. Biosci., 2016; 3: 27

[23] Zubowska M., Zalewska-Szewczyk B., Stengert W., Mycko K., Młynarski W.: Ciężki niedobór witaminy B12 o nieznanej etiologii u 10-miesięcznej dziewczynki. Hematologia, 2011; 2: 92-97

[24] Gruber B.M.: B-group vitamins: Chemoprevention? Adv. Clin. Exp. Med., 2016; 25: 561-568

[25] Hasan T., Arora R., Bansal A.K., Bhattacharya R., Sharma G.S., Singh L.R.: Disturbed homocysteine metabolism is associated with cancer. Exp. Mol. Med., 2019; 51: 1-13

[26] Łukasik M., Karmalska J., Szutowski M.M., Łukaszkiewicz J.: Wpływ metylacji DNA na funkcjonowanie genomu. Biul. Wydz. Farm. WUM, 2009; 2: 13-18

[27] Liu Z., Cui C., Wang X., Fernandez-Escobar A., Wu Q., Xu K., Mao J., Jin M., Wang K.: Plasma levels of homocysteine and the occurrence and progression of rectal cancer. Med. Sci. Monit., 2018; 24: 1776-1783

[28] Fenech M.: Folate (vitamin B9) and vitamin B12 and their function in the maintenance of nuclear and mitochondrial genome integrity. Mutat. Res., 2012; 733: 21-33 
[29] Choi S.W., Mason J.B.: Folate and carcinogenesis: An integrated scheme. J. Nutr., 2000; 130: 129-132

[30] Zhang D., Wen X., Wu W., Guo Y., Cui W.: Elevated homocysteine level and folate deficiency associated with increased overall risk of carcinogenesis: Meta-analysis of 83 case-control studies involving 35,758 individuals. PLoS One, 2015; 10: e0123423

[31] Sauer J., Mason J.B., Choi S.W.: Too much folate: A risk factor for cancer and cardiovascular disease? Curr. Opin. Clin. Nutr. Metab. Care, 2009; 12: 30-36

[32] Czeczot H.: Kwas foliowy w fizjologii i patologii. Postępy Hig. Med. Dośw., 2008; 62: 405-419

[33] Kim Y.I.: Will mandatory folic acid fortification prevent or promote cancer? Am. J. Clin. Nutr., 2004; 80: 1123-1128

[34] Mason J.B.: Folate, cancer risk, and the Greek god, Proteus: A tale of two chameleons. Nutr. Rev., 2009; 67: 206-212

[35] Duthie S.J.: Folate and cancer: How DNA damage, repair and methylation impact on colon carcinogenesis. J. Inherit. Metab. Dis., 2011; 34: 101-109

[36] Curtin K., Samowitz W.S., Ulrich C.M., Wolff R.K., Herrick J.S., Caan B.J., Slattery M.L.: Nutrients in folate-mediated, one-carbon metabolism and the risk of rectal tumors in men and women. Nutr. Cancer, 2011; 63: 357-366

[37] Boyer A.S., Walter D., Sørensen C.S.: DNA replication and cancer: From dysfunctional replication origin activities to therapeutic opportunities. Semin. Cancer Biol., 2016; 37-38: 16-25
[38] Gaillard H., García-Muse T., Aguilera A.: Replication stress and cancer. Nat. Rev. Cancer, 2015; 15: 276-289

[39] Miles L.: Vitamin B12 status and neurological function in older people. PhD thesis, London School of Hygiene \& Tropical Medicine. 2016, DOI: https://doi.org/10.17037/PUBS.02837733

[40] Zboch M., Gwizdak-Siwkowska B., Serafin J., Śmigórski K., Tyfel P., Leszek J.: Niedobór witaminy B12 jako czynnik rozwoju procesu otępiennego. Med. Rodz., 2010; 2010: 14-19

[41] Kosgei V.J., Coelho D., Guéant-Rodriguez R.M., Guéant J.L.: Sirt1-PPARS cross-talk in complex metabolic diseases and inherited disorders of the one carbon metabolism. Cells, 2020; 9: 1882

[42] Ghemrawi R., Khair M.: Endoplasmic reticulum stress and unfolded protein response in neurodegenerative diseases. Int. J. Mol. Sci., 2020; 21: 6127

[43] Palmer A.M., Kamynina E., Field M.S., Stover P.J.: Folate rescues vitamin $B_{12}$ depletion-induced inhibition of nuclear thymidylate biosynthesis and genome instability. Proc. Natl. Acad. Sci. USA, 2017; 114: E4095-E4102

[44] Harrington D.J.: Laboratory assessment of vitamin B12 status. J. Clin. Pathol., 2017; 70: 168-173

[45] Vashi P., Edwin P., Popiel B., Lammersfeld C., Gupta D.: Methylmalonic acid and homocysteine as indicators of vitamin B-12 deficiency in cancer. PLoS One, 2016; 11: e0147843 